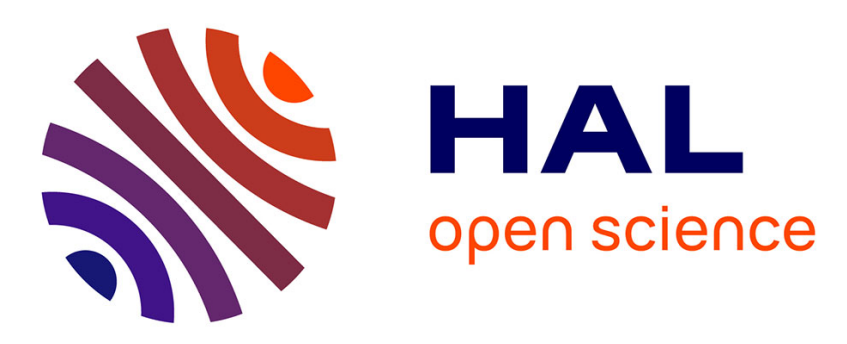

\title{
Early detection of biofilm development on stone monuments thanks to pulsed IRT and SVD
}

Stéphanie Eyssautier, Kamel Mouhoubi, Fany Reffluveille, Jean Luc Bodnar

\section{To cite this version:}

Stéphanie Eyssautier, Kamel Mouhoubi, Fany Reffluveille, Jean Luc Bodnar. Early detection of biofilm development on stone monuments thanks to pulsed IRT and SVD. Optics for Arts, Architecture, and Archaeology VII, Jun 2019, Munich, France. SPIE, pp.53, 10.1117/12.2526073 . hal-02945594

\author{
HAL Id: hal-02945594 \\ https://hal.science/hal-02945594
}

Submitted on 12 Nov 2021

HAL is a multi-disciplinary open access archive for the deposit and dissemination of scientific research documents, whether they are published or not. The documents may come from teaching and research institutions in France or abroad, or from public or private research centers.
L'archive ouverte pluridisciplinaire HAL, est destinée au dépôt et à la diffusion de documents scientifiques de niveau recherche, publiés ou non, émanant des établissements d'enseignement et de recherche français ou étrangers, des laboratoires publics ou privés. 
